\title{
Uromodulin and Chronic Kidney Disease
}

\author{
Karl Lhotta \\ Department of Nephrology and Dialysis, Academic Teaching Hospital Feldkirch, Feldkirch, Austria
}

\section{Key Words}

Uromodulin - Tamm-Horsfall protein · Chronic kidney

disease $\cdot$ Glomerular filtration rate, reduced

\begin{abstract}
Uromodulin (Tamm-Horsfall protein) is produced in the kidney by cells of the thick ascending limb and distal tubule. Recent genetic studies suggest a role of uromodulin in chronic kidney disease. Mutations in the UMOD gene cause uromodulin storage disease. They code for amino acid substitutions that lead to misfolding of the molecule and its retention in the endoplasmic reticulum. Single nucleotide polymorphisms in the region of the UMOD gene have been shown to be associated with chronic kidney disease and reduced glomerular filtration rate. These polymorphisms affect uromodulin concentration in the urine, and lower genetically determined urinary uromodulin concentrations seem to protect against renal disease. Chronic kidney disease is associated with higher serum levels of uromodulin. From animal experiments and human studies it is hypothesized that uromodulin entering the renal interstitium either by basolateral secretion or urinary back-leakage in damaged tubuli interacts with and stimulates cells of the immune system and thereby causes inflammation and progression of chronic kidney disease.

Copyright $\odot 2010$ S. Karger AG, Basel
\end{abstract}

\section{Introduction}

Uromodulin or Tamm-Horsfall protein is a $95-\mathrm{kDa}$ glycoprotein exclusively synthesized by the cells of the thick ascending limb (TAL) and early distal convoluted tubule in the kidney. It consists of 640 amino acids including 48 cysteine residues [1]. Seven of eight potential glycosylation sites are occupied by $\mathrm{N}$-linked complex multiantennary glycans comprising one third of the molecular weight [2]. Uromodulin is produced in the endoplasmic reticulum (ER), shuttled to the apical cell membrane as a GPI-linked molecule and released into the urine by proteoly tic cleavage. Healthy individuals excrete about 20-70 mg of uromodulin per day, making it the most abundant protein in the urine. Uromodulin forms a gel on the surface of the TAL cells, which is important for water impermeability. It protects against stone disease by preventing aggregation of calcium oxalate crystals. Uromodulin binds to type 1 fimbriae of Escherichia coli and thereby blocks colonization of urothelial cells [3]. Uromodulin knockout mice have an impaired capacity to concentrate urine and are prone to renal stone disease and urinary tract infections [4-6].

Recent genetic studies have renewed interest in the biology of uromodulin. Mutations in the UMOD gene on chromosome 16p12.3 cause the so-called uromodulin storage diseases familial juvenile hyperuricemic nephropathy, medullary cystic kidney disease type 2 and glomerulocystic kidney disease [7-10]. Second, two ge-

Dr. Karl Lhotta

Academic Teaching Hospital Feldkirch

Carinagasse 47

AT-6800 Feldkirch (Austria)

Tel. +435522 303 2700, Fax +435522 303 7506, E-Mail karl.lhotta@lkhf.at 
nome-wide association studies in the general population showed that several significant single nucleotide polymorphisms in the UMOD gene region were associated with chronic kidney disease (CKD) and estimated glomerular filtration rate $[11,12]$.

\section{Uromodulin Storage Diseases}

These autosomal dominant diseases clinically present with hyperuricemia and gout with a low renal fractional excretion of uric acid, and progressive renal failure leading to ESRD in adulthood [13]. Renal cysts are a frequent finding and renal histology shows tubular atrophy and interstitial fibrosis with mild inflammatory infiltration. Urinary uromodulin excretion decreases during childhood and reaches very low levels in adulthood $[14,15]$. To date, more than 50 UMOD mutations have been identified. They are mainly localized in exons 3 and 4 , and most of them are missense mutations or small inframe deletions. Many of them cause an amino acid change at cysteine sites. Cysteine residues form disulfide bonds and determine correct protein folding. Therefore, it is assumed that UMOD mutations causing uromodulin storage disease lead to defective protein folding. Misfolded immature uromodulin is retained in the ER and not expressed at or released by the apical cell membrane. In renal biopsies large, dense intracellular deposits of uromodulin in TAL cells can be visualized by immunostaining using antiuromodulin antibodies [9]. Electron microscopy of TAL cells shows bundles of hyperplastic ER containing moderately electron-dense storage material [16]. In vitro experiments of various renal epithelial cell lines transfected with mutant UMOD cDNAs indeed showed that mutated uromodulin is retained intracellularly [17-21]. Depending on the extent of maturation, Williams et al. [20] classified mutants into group A with reduced (50\%) and group B with almost absent (25\%) maturation. Group A mutants were also localized to the cell membrane, whereas group B mutants continued to be completely retained by the ER. There is, however, no correlation between the severity of the maturation defect and the clinical expression of the disease. Accumulation of misfolded proteins in the ER causes ER stress and the unfolded protein response with increased synthesis of chaperones and foldases and activation of ER-associated degradation in order to eliminate the misfolded proteins [22]. When the capacity of the cell to remove these molecules is working to full capacity, the unfolded protein response may trigger apoptosis and autophagy or alternatively lead to cell activation via MAP kinases and NF- $\mathrm{KB}$. It is highly likely that these pathways eventually result in TAL cell damage and loss with progressive renal failure. We were able to show a significant number of apoptotic tubular epithelial cells in a biopsy of a patient with uromodulin storage disease [23]. In vitro, chaperones such as colchicine and sodium 4-phenylbutyrate increased uromodulin transport to the cell membrane and secretion in transfected cell lines and reduced apoptosis [17]. Therefore, such substances may be good candidates for the treatment of uromodulin storage disease. Jennings et al. [19] reported normal basolateral secretion of mutated uromodulin and increased serum levels in some patients. Higher basolateral secretion of uromodulin may cause an inflammatory response and tubulointerstitial damage (see below). Uromodulin is also located in primary cilia of TAL cells [24]. Studies in renal biopsies of patients and cell culture experiments in transfected cells showed decreased ciliary uromodulin expression in uromodulin storage disease [24]. As hereditary renal cystic diseases are caused by defects in ciliary proteins, this finding may explain the frequent presence of renal cysts in uromodulin storage diseases.

Why patients with uromodulin storage disease have a low fractional renal excretion of uric acid and consequent hyperuricemia remains a matter of debate. The common view is that hyperuricemia is a consequence of volume depletion. Scolari et al. [13] hypothesize that due to the lack of uromodulin on the luminal surface of the TAL, water reabsorption is increased. This would lead to a reduction of sodium and chloride reabsorption by the TAL, which is compensated by an increase in proximal tubular uptake, a process that is coupled to urate reabsorption. They also showed that a reduction in urine-concentrating capability was associated with higher uric acid serum levels in these patients. In contrast, Kotanko et al. [25] did not find any signs of volume depletion in their patients, who had normal renin and aldosterone levels. In addition, despite saline infusion they retained their low fractional uric acid excretion. Whatever the cause of hyperuricemia, treatment with uricosuric drugs such as benzbromarone can normalize renal uric acid excretion in these patients [23].

\section{Uromodulin and CKD}

As stated above, a genome-wide association study in 41,343 participants including 4,320 patients with CKD showed a significant correlation between SNPs in the 
UMOD gene region and CKD and estimated glomerular filtration rate [11]. This association was confirmed in an even larger meta-analysis published recently [12]. In particular SNP rs12917707 located $3.6 \mathrm{~kb}$ upstream of the UMOD gene was associated with CKD. The minor $\mathrm{T}$ allele of that SNP conferred a $20 \%$ reduction in risk for incident CKD over almost 15 years of follow-up in the Atherosclerosis Risk in Communities (ARIC) Study. To follow this further, Köttgen et al. [26] found in a casecontrol study of 242 CKD patients that high urinary uromodulin excretion was associated with the development of CKD 10 years later. Cases had 50\% higher uromodulin levels than did controls without CKD. In addition, uromodulin excretion was lower with each copy of the minor C allele of SNP rs4293393 in the UMOD gene region, which is associated with a lower risk of CKD. The frequency of the minor $\mathrm{C}$ allele is 0.18 and the mean urinary uromodulin concentrations are 5.5, 3.1 and 1.5 $\mu \mathrm{g} / \mathrm{ml}$ for 0,1 or 2 copies of the $\mathrm{C}$ allele, respectively. This study suggests that high urinary uromodulin excretion, which is genetically determined, may be a risk factor for CKD.

The pathogenetic link between high uromodulin excretion and CKD is at present unknown. So far, low uromodulin levels have mostly been considered a consequence of TAL damage and correlate with reduced renal function in various nephropathies [27-30]. How could high uromodulin synthesis and excretion cause or accelerate CKD? There is evidence that the immune system may play a central role. Uromodulin reacts with various cells of the immune system, possibly by nonspecific binding of its carbohydrates with cell surface receptors of these cells. The binding of uromodulin to neutrophils induces synthesis of IL-8, provokes the respiratory burst and degranulation [31,32] and stimulates chemotaxis and phagocytosis [33]. Monocytes are induced to secrete IL-1 $\beta$, IL- 6 and TNF- $\alpha$ [34]. Uromodulin increases the expression of the IL-2 receptor and HLA class II molecules on lymphocytes and stimulates cell proliferation [34]. Immature dendritic cells are transferred to a mature phenotype via Toll-like receptor-4 signaling [35]. Incubation of venous blood with uromodulin causes a dosedependent increase in synthesis and secretion of TNF- $\alpha$, IL-1 $\beta$, IL- 6 and IL- 8 by leukocytes [36]. In animal models, repeated intravenous administration of uromodulin causes a specific immune response. Uromodulin autoantibodies are detected in these animals and tubulointerstitial nephritis affecting the distal nephron segments, where uromodulin is synthesized, develops [37-41]. This interstitial nephritis is mainly caused by a cellular im- mune response and can be transferred with lymphocytes and spleen cells [41]. Whether a specific immune response to uromodulin plays a role in human disease is presently unknown. Antiuromodulin antibodies are detected in acute pyelonephritis, reflux nephropathy and other nephropathies, but also in healthy individuals and patients with hepatitis [42-46]. These antibodies usually are of very low affinity [47]. Immunoglobulins also bind in an unspecific way to carbohydrates of uromodulin [48]. Therefore, it is likely that the described antiuromodulin antibodies in humans are not specific and are most likely an artifact. Together, there is no clear evidence that a specific humoral or cellular immune response to uromodulin plays a role in human renal disease.

Recently Prajczer et al. [36] presented new data that may shed some light on the role of uromodulin in CKD. They measured uromodulin in serum and urine of 14 healthy individuals and $77 \mathrm{CKD}$ patients. In serum, uromodulin levels lower by a factor of 1,000 as compared to urine were found in patients and controls $(\mathrm{ng} / \mathrm{ml}$ range in serum vs. $\mathrm{mg} / \mathrm{l}$ range in urine). In agreement with others, they found that the lower the GFR the lower the urinary uromodulin excretion. Low urinary uromodulin was also associated with tubular atrophy and interstitial infiltration as detected in renal biopsies. In serum, however, there was a trend towards higher uromodulin levels in individuals with low GFR. Furthermore, high serum uromodulin was associated with higher serum levels of the proinflammatory cytokines TNF- $\alpha$, IL-1 $\beta$, IL-6, IL8 , and of vascular endothelial growth factor VEGF, but not hepatocyte growth factor HGF. The authors speculate that uromodulin entering the renal interstitium, either via basolateral secretion by TAL cells or via backleakage of urine, may react with cells of the immune system and stimulate an inflammatory response, which then promotes further tubulointerstitial damage. Studying monolayers of uromodulin-transfected LLC-PK1 cells (porcine proximal tubular cells) Jennings et al. [19] found that around $10 \%$ of uromodulin is secreted basolaterally. Other studies that showed interstitial deposits of uromodulin in conditions such as reflux nephropathy, glomerulonephritis, interstitial nephritis and in renal allografts, often in the vicinity of disrupted tubules, support the presence of uromodulin back-leakage in damaged kidneys [42, 49-52]. The finding that these deposits are frequently surrounded by cellular infiltration also fits the concept. 


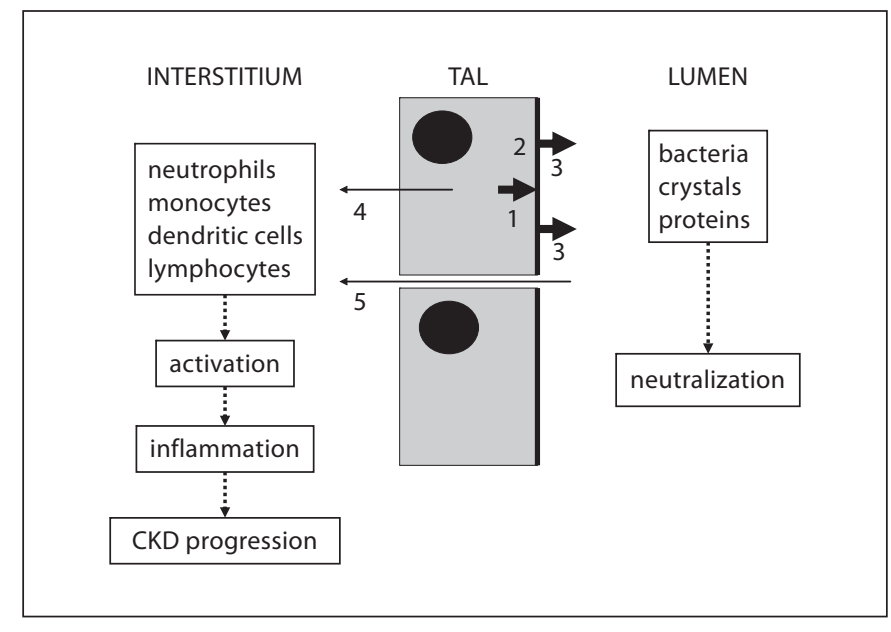

Fig. 1. Uromodulin synthesized in the TAL is targeted primarily to the apical membrane of the TAL cells (1), where it forms a gel on the cell surface (2) and is eventually released into the tubular lumen (3). A small proportion of uromodulin may be secreted basolaterally (4). Uromodulin also enters the interstitium by tubular back-leakage (5), especially in damaged tubuli. Binding of uromodulin to bacteria or crystals in the urine is beneficial, whereas its interaction with cells of the immune system in the renal interstitium causes inflammation and further renal damage.

\section{A Unifying Hypothesis}

Figure 1 summarizes the different effects of uromodulin present in the urine or interstitium. Uromodulin is, by its carbohydrate structures, a very sticky multipurpose molecule. It binds and neutralizes all sorts of objects that might appear in urine such as crystals, bacteria, various proteins and exosomes [53]. Once uromodulin finds its way into the renal interstitium, either by cellular secre- tion or urinary back-leak, this stickiness becomes dangerous. Uromodulin will bind to cells of the immune system such as neutrophils, monocytes, dendritic cells and lymphocytes and thereby stimulate in an unspecific way an already ongoing immune reaction that may lead to tubulointerstital damage and progressive renal failure. The data of Prajczer et al. [36] and Köttgen et al. [26] suggest that high urine or serum levels of uromodulin are potentially dangerous. Therefore, downregulation of synthesis and secretion of uromodulin might be a therapeutic option for slowing CKD progression. To be able to achieve this, we have to understand the factors that, in addition to genetics, regulate uromodulin secretion. Data on this subject are scarce, but it appears that a high-salt or highprotein diet, loop diuretics and polyuria all may increase uromodulin secretion [54-57]. The recent data on uromodulin will certainly stimulate further research in this field and make it a prime target for further studies of the pathogenesis and progression of CKD.

Lastly, it should also be mentioned that uromodulin may have renoprotective properties. In the mouse, renal ischemia and reperfusion stimulate uromodulin expression. In this model, uromodulin knockout mice show more tubular necrosis and inflammation and a greater impairment in renal function than do normal mice [58]. Future research into the role of uromodulin in kidney physiology and disease certainly holds some surprises.

\section{Acknowledgment}

I would like to thank Florian Kronenberg, Division of Genetic Epidemiology, Innsbruck Medical University, for his critical review of the manuscript.

\section{References}

Pennica D, Kohr WJ, Kuang WJ, Glaister D, Aggarwal BB, Chen EY, Goeddel DV: Identification of human uromodulin as the TammHorsfall urinary glycoprotein. Science 1987; 236:83-88.

2 van Rooijen JJ, Voskamp AF, Kamerling JP, Vliegenthart JF: Glycosylation sites and sitespecific glycosylation in human TammHorsfall glycoprotein. Glycobiology 1999;9: 21-30.

-3 Weichhart T, Zlabinger GJ, Saemann MD: The multiple functions of Tamm-Horsfall protein in human health and disease: a mystery clears up. Wien Klin Wochenschr 2005; 117:316-322.

\footnotetext{
4 Bachmann S, Mutig K, Bates J, Welker P, Geist B, Gross V, Luft FC, Alenina N, Bader M, Thiele BJ, Prasadan K, Raffi HS, Kumar S: Renal effects of Tamm-Horsfall protein (uromodulin) deficiency in mice. Am J Physiol Renal Physiol 2005;288:F559-F567.

5 Mo L, Huang HY, Zhu XH, Shapiro E, Hasty $\mathrm{DL}, \mathrm{Wu}$ XR: Tamm-Horsfall protein is a critical renal defense factor protecting against calcium oxalate crystal formation. Kidney Int 2004;66:1159-1166.
} 
-6 Bates JM, Raffi HM, Prasadan K, Mascarenhas R, Laszik Z, Maeda N, Hultgren SJ, Kumar S: Tamm-Horsfall protein knockout mice are more prone to urinary tract infection: rapid communication. Kidney Int 2004; 65:791-797.

>7 Hart TC, Gorry MC, Hart PS, Woodard AS, Shihabi Z, Sandhu J, Shirts B, Xu L, Zhu H, Barmada MM, Bleyer AJ: Mutations of the UMOD gene are responsible for medullary cystic kidney disease 2 and familial juvenile hyperuricaemic nephropathy. J Med Genet 2002;39:882-892.

-8 Turner JJ, Stacey JM, Harding B, Kotanko P, Lhotta K, Puig JG, Roberts I, Torres RJ, Thakker RV: Uromodulin mutations cause familial juvenile hyperuricemic nephropathy. J Clin Endocrinol Metab 2003;88:13981401.

-9 Dahan K, Devuyst O, Smaers M, Vertommen D, Loute G, Poux JM, Viron B, Jacquot C, Gagnadoux MF, Chauveau D, Buchler M, Cochat P, Cosyns JP, Mougenot B, Rider MH, Antignac C, Verellen-Dumoulin C, Pirson Y: A cluster of mutations in the UMOD gene causes familial juvenile hyperuricemic nephropathy with abnormal expression of uromodulin. J Am Soc Nephrol 2003;14:28832893.

10 Rampoldi L, Caridi G, Santon D, Boaretto F, Bernascone I, Lamorte G, Tardanico R, Dagnino M, Colussi G, Scolari F, Ghiggeri GM, Amoroso A, Casari G: Allelism of MCKD, FJHN and GCKD caused by impairment of uromodulin export dynamics. Hum Mol Genet 2003;12:3369-3384.

11 Köttgen A, Glazer NL, Dehghan A, Hwang SJ, Katz R, Li M, Yang Q, Gudnason V, Launer LJ, Harris TB, Smith AV, Arking DE, Astor BC, Boerwinkle E, Ehret GB, Ruczinski I, Scharpf RB, Ida Chen YD, de Boer IH, Haritunians T, Lumley T, Sarnak M, Siscovick D, Benjamin EJ, Levy D, Upadhyay A, Aulchenko YS, Hofman A, Rivadeneira F, Uitterlinden AG, van Duijn CM, Chasman DI, Pare G, Ridker PM, Kao WH, Witteman JC, Coresh J, Shlipak MG, Fox CS: Multiple loci associated with indices of renal function and chronic kidney disease. Nat Genet 2009, Epub ahead of print.

12 Köttgen A, Pattaro C, Boger CA, Fuchsberger C, Olden M, Glazer NL, Parsa A, Gao X, Yang Q, Smith AV, O'Connell JR, Li M, Schmidt $\mathrm{H}$, Tanaka T, Isaacs A, Ketkar S, Hwang SJ, Johnson AD, Dehghan A, Teumer A, Pare G, Atkinson EJ, Zeller T, Lohman K, Cornelis MC, Probst-Hensch NM, Kronenberg F, Tonjes A, Hayward C, Aspelund T, Eiriksdottir G, Launer LJ, Harris TB, Rampersaud E, Mitchell BD, Arking DE, Boerwinkle E, Struchalin M, Cavalieri M, Singleton A, Giallauria F, Metter J, de Boer IH, Haritunians T, Lumley T, Siscovick D, Psaty BM, Zillikens MC, Oostra BA, Feitosa M, Province M, de Andrade M, Turner ST, Schillert A, Ziegler A, Wild PS, Schnabel RB, Wilde S, Munzel TF, Leak TS, Illig T, Klopp
N, Meisinger C, Wichmann HE, Koenig W, Zgaga L, Zemunik T, Kolcic I, Minelli C, Hu FB, Johansson A, Igl W, Zaboli G, Wild SH, Wright AF, Campbell H, Ellinghaus D, Schreiber S, Aulchenko YS, Felix JF, Rivadeneira F, Uitterlinden AG, Hofman A, Imboden M, Nitsch D, Brandstatter A, Kollerits B, Kedenko L, Magi R, Stumvoll M, Kovacs P, Boban M, Campbell S, Endlich K, Volzke H, Kroemer HK, Nauck M, Volker U, Polasek O, Vitart V, Badola S, Parker AN, Ridker PM, Kardia SL, Blankenberg S, Liu Y, Curhan GC, Franke A, Rochat T, Paulweber B, Prokopenko I, Wang W, Gudnason V, Shuldiner AR, Coresh J, Schmidt R, Ferrucci L, Shlipak MG, van Duijn CM, Borecki I, Kramer BK, Rudan I, Gyllensten U, Wilson JF, Witteman JC, Pramstaller PP, Rettig R, Hastie N, Chasman DI, Kao WH, Heid IM, Fox CS: New loci associated with kidney function and chronic kidney disease. Nat Genet 2010;42:376-384.

13 Scolari F, Caridi G, Rampoldi L, Tardanico R, Izzi C, Pirulli D, Amoroso A, Casari G, Ghiggeri GM: Uromodulin storage diseases: clinical aspects and mechanisms. Am J Kidney Dis 2004;44:987-999.

14 Lhotta K, Gehringer A, Jennings P, Kronenberg F, Brezinka C, Andersone I, Strazdins V: Familial juvenile hyperuricemic nephropathy: report on a new mutation and a pregnancy. Clin Nephrol 2009;71:80-83.

15 Bleyer AJ, Hart TC, Shihabi Z, Robins V, Hoyer JR: Mutations in the uromodulin gene decrease urinary excretion of Tamm-Horsfall protein. Kidney Int 2004;66:974-977.

-16 Nasr SH, Lucia JP, Galgano SJ, Markowitz GS, D'Agati VD: Uromodulin storage disease. Kidney Int 2008;73:971-976.

17 Choi SW, Ryu OH, Choi SJ, Song IS, Bleyer AJ, Hart TC: Mutant Tamm-Horsfall glycoprotein accumulation in endoplasmic reticulum induces apoptosis reversed by colchicine and sodium 4-phenylbutyrate. J Am Soc Nephrol 2005; 16:3006-3014.

18 Bernascone I, Vavassori S, Di Pentima A, Santambrogio S, Lamorte G, Amoroso A, Scolari F, Ghiggeri GM, Casari G, Polishchuk R, Rampoldi L: Defective intracellular trafficking of uromodulin mutant isoforms. Traffic 2006; 7:1567-1579.

19 Jennings P, Aydin S, Kotanko P, Lechner J, Lhotta K, Williams S, Thakker RV, Pfaller W: Membrane targeting and secretion of mutant uromodulin in familial juvenile hyperuricemic nephropathy. J Am Soc Nephrol 2007;18:264-273.

20 Williams SE, Reed AA, Galvanovskis J, Antignac C, Goodship T, Karet FE, Kotanko P, Lhotta K, Moriniere V, Williams P, Wong W, Rorsman P, Thakker RV: Uromodulin mutations causing familial juvenile hyperuricaemic nephropathy lead to protein maturation defects and retention in the endoplasmic reticulum. Hum Mol Genet 2009;18:29632974.

21 Vylet'al P, Kublova M, Kalbacova M, Hodanova K, Baresova V, Stiburkova B, Sikora J,
Hulkova H, Zivny J, Majewski J, Simmonds A, Fryns JP, Venkat-Raman G, Elleder M, Kmoch S: Alterations of uromodulin biology: a common denominator of the genetically heterogeneous FJHN/MCKD syndrome. Kidney Int 2006;70:1155-1169.

22 Kitamura M: Endoplasmic reticulum stress and unfolded protein response in renal pathophysiology: Janus faces. Am J Physiol Renal Physiol 2008;295:F323-F334.

23 Lhotta K, Gruber J, Sgonc R, Fend F, König $\mathrm{P}$ : Apoptosis of tubular epithelial cells in familial juvenile gouty nephropathy. Nephron 1998;79:340-344.

24 Zaucke F, Boehnlein JM, Steffens S, Polishchuk RS, Rampoldi L, Fischer A, Pasch A, Boehm CW, Baasner A, Attanasio M, Hoppe B, Hopfer H, Beck BB, Sayer JA, Hildebrandt F, Wolf MT: Uromodulin is expressed in renal primary cilia and UMOD mutations result in decreased ciliary uromodulin expression. Hum Mol Genet 2010;19:1985-1997.

25 Kotanko P, Bajraktari I, Lhotta K: Hyperuricemia in patients with familial juvenile hyperuricemic nephropathy (FJHN) is not caused by volume depletion (abstract). J Am Soc Nephrol 2003; 14:114A.

- 26 Köttgen A, Hwang SJ, Larson MG, Van Eyk JE, Fu Q, Benjamin EJ, Dehghan A, Glazer NL, Kao WH, Harris TB, Gudnason V, Shlipak MG, Yang Q, Coresh J, Levy D, Fox CS: Uromodulin levels associate with a common UMOD variant and risk for incident CKD. J Am Soc Nephrol 2010;21:337-344.

27 Lynn KL, Marshall RD: Excretion of TammHorsfall glycoprotein in renal disease. Clin Nephrol 1984;22:253-257.

28 Thornley C, Dawnay A, Cattell WR: Human Tamm-Horsfall glycoprotein: urinary and plasma levels in normal subjects and patients with renal disease determined by a fully validated radioimmunoassay. Clin Sci (Lond) 1985;68:529-535.

-29 Torffvit O, Jorgensen PE, Kamper AL, Holstein-Rathlou NH, Leyssac PP, Poulsen SS, Strandgaard S: Urinary excretion of TammHorsfall protein and epidermal growth factor in chronic nephropathy. Nephron 1998; 79:167-172.

30 Chakraborty J, Below AA, Solaiman D: Tamm-Horsfall protein in patients with kidney damage and diabetes. Urol Res 2004;32: 79-83.

- 31 Kreft B, Jabs WJ, Laskay T, Klinger M, Solbach W, Kumar S, van Zandbergen G: Polarized expression of Tamm-Horsfall protein by renal tubular epithelial cells activates human granulocytes. Infect Immun 2002;70:26502656.

32 Horton JK, Davies M, Topley N, Thomas D, Williams JD: Activation of the inflammatory response of neutrophils by Tamm-Horsfall glycoprotein. Kidney Int 1990;37:717-726.

33 Wimmer T, Cohen G, Saemann MD, Horl WH: Effects of Tamm-Horsfall protein on polymorphonuclear leukocyte function. Nephrol Dial Transplant 2004;19:2192-2197. 
-34 Yu CL, Tsai CY, Lin WM, Liao TS, Chen HL, Sun KH, Chen KH: Tamm-Horsfall urinary glycoprotein enhances monokine release and augments lymphocyte proliferation. Immunopharmacology 1993;26:249-258.

- 35 Saemann MD, Weichhart T, Zeyda M Staffler G, Schunn M, Stuhlmeier KM, Sobanov Y, Stulnig TM, Akira S, von Gabain A, von Ahsen U, Horl WH, Zlabinger GJ: Tamm-Horsfall glycoprotein links innate immune cell activation with adaptive immunity via a Toll-like receptor-4-dependent mechanism. J Clin Invest 2005;115:468-475.

-36 Prajczer S, Heidenreich U, Pfaller W, Kotanko P, Lhotta K, Jennings P: Evidence for a role of uromodulin in chronic kidney disease progression. Nephrol Dial Transplant 2010; 25:1896-1903.

-37 Hoyer JR: Tubulointerstitial immune complex nephritis in rats immunized with Tamm-Horsfall protein. Kidney Int 1980;17: 284-292.

>38 Berke ES, Mayrer AR, Miniter P, Andriole VT: Tubulointerstitial nephritis in rabbits challenged with homologous Tamm-Horsfall protein: the role of endotoxin. Clin Exp Immunol 1983;53:562-572.

-39 Andriole VT: The role of Tamm-Horsfall protein in the pathogenesis of reflux nephropathy and chronic pyelonephritis. Yale J Biol Med 1985;58:91-100.

-40 Fasth A, Hoyer JR, Seiler MW: Renal tubular immune complex formation in mice immunized with Tamm-Horsfall protein. Am J Pathol 1986;125:555-562.

-41 Sato K, Oguchi H, Yoshie T, Koiwai T: Tubulointerstitial nephritis induced by TammHorsfall protein sensitization in guinea pigs. Virchows Arch B Cell Pathol Incl Mol Pathol 1990;58:357-363.
42 Chambers R, Groufsky A, Hunt JS, Lynn KL, McGiven AR: Relationship of abnormal Tamm-Horsfall glycoprotein localization to renal morphology and function. Clin Nephrol 1986;26:21-26.

43 Lindberg J, Fasth A, Norkrans G, Nilsson LA: Autoantibodies to Tamm-Horsfall protein in acute and chronic hepatitis. Int Arch Allergy Appl Immunol 1983;70:146-150.

44 Pinto M, Oron C, Pinto O, Peer G: Natural autoantibodies against Tamm-Horsfall glycoprotein in normal individuals in relation to age and in adult patients with kidney diseases. Jpn J Exp Med 1990;60:197-202.

45 Fasth A, Bengtsson U, Kaijser B, Wieslander $\mathrm{J}$ : Antibodies to Tamm-Horsfall protein associated with renal damage and urinary tract infections in adults. Kidney Int 1981;20:500504.

46 Marier R, Fong E, Jansen M, Hodson CJ, Richards F, Andriole VT: Antibody to Tamm-Horsfall protein in patients with urinary tract obstruction and vesicoureteral reflux. J Infect Dis 1978;138:781-790.

47 Hunt JS, Groufsky A, Lynn KL: Studies to assess the biological relevance of anti-TammHorsfall protein antibodies detected by direct-binding enzyme-linked immunosorbent assay. Clin Sci (Lond) 1987;73:479-487.

48 Rhodes DC, Hinsman EJ, Rhodes JA: TammHorsfall glycoprotein binds IgG with high affinity. Kidney Int 1993;44:1014-1021.

49 Zager RA, Cotran RS, Hoyer JR: Pathologic localization of Tamm-Horsfall protein in interstitial deposits in renal disease. Lab Invest 1978;38:52-57.

50 Resnick JS, Sisson S, Vernier RL: TammHorsfall protein. Abnormal localization in renal disease. Lab Invest 1978;38:550-555.
51 Howie AJ, Brewer DB: Extra-tubular deposits of Tamm-Horsfall protein in renal allografts. J Pathol 1983;139:193-206.

52 Akioka Y, Chikamoto H, Horita S, Yago R, Tanabe K, Yamaguchi Y, Hattori M: Screening of vesicoureteral reflux in pediatric patients with kidney transplantation showing non-specific interstitial fibrosis and tubular atrophy with interstitial Tamm-Horsfall protein deposits in protocol allograft biopsy. Clin Transplant 2009;23(suppl 20):2-5.

53 Fernandez-Llama P, Khositseth S, Gonzales PA, Star RA, Pisitkun T, Knepper MA: Tamm-Horsfall protein and urinary exosome isolation. Kidney Int 2010;77:736-742.

54 Bachmann S, Dawnay AB, Bouby N, Bankir L: Tamm-Horsfall protein excretion during chronic alterations in urinary concentration and protein intake in the rat. Ren Physiol Biochem 1991;14:236-245.

55 Dulawa J, Kokot M, Kokot F: Effects of furosemide, propranolol and nifedipine on urinary excretion of Tamm-Horsfall protein in patients with arterial hypertension (in Polish). Pol Arch Med Wewn 1992;88:212-218.

56 Thulesen J, Jorgensen PE, Torffvit O, Nexo E, Poulsen SS: Urinary excretion of epidermal growth factor and Tamm-Horsfall protein in three rat models with increased renal excretion of urine. Regul Pept 1997;72:179-186.

57 Ying WZ, Sanders PW: Dietary salt regulates expression of Tamm-Horsfall glycoprotein in rats. Kidney Int 1998;54:1150-1156.

58 El-Achkar TM, Wu XR, Rauchman M, McCracken R, Kiefer S, Dagher PC: TammHorsfall protein protects the kidney from ischemic injury by decreasing inflammation and altering TLR4 expression. Am J Physiol Renal Physiol 2008;295:F534-F544. 